Keith M. Carlson

Keith $M$. Carlson is an assistant vice president at the Federat Reserve Bank of St. Louis. Thomas A. Pollmann provided research assistance.

\title{
Federal Budget Trends and the 1981 Reagan Economic Plan
}

I N FARLY 1981, a newly inaugurated Ronald Reagan announced an economic plan which included goals of "an immediate, substantial, and sustained reduction in the growth of federal expenditures [and] a significant reduction in federal tax rates ..." After two terms in office, it seems time to examine the original Reagan budget plan in light of the actual performance over the $1980 \mathrm{~s}$. Although the budget plan had far-reaching economic and social consequences, this article focuses on the extent to which the initial budget projections were realized."

First, the 1981 economic setting, which provided the underlying rationale for the keagan plan, is summarized. Then, because the budget and economic conditions are interrelated, the $1981 \mathrm{eco}^{-}$ nomic assumptions are examined in retrospect. This is followed by a comparison of planned and realized changes in federal outlays and receipts. The article concludes with an evaluation of the 1981 budget plan.

\section{TIV 1981 LCONOMIC FONECASTIN PRTMOSPEOT}

When the Reagan administration began prepar ing its budget in late 1980 and earty 1981, the L,S. economy was recovering from a brief recession in the first half of 1980. Output was growing sluggishly for a recovery phase of the business cycle, unemployment was well above 7 percent of the labor force and productivity, as measured by output per hour, was declining. Prices generally were increasing at double-digit rates and interest rates reflected the high rate of inflation. The federal budget deficit for fiscal 1980 was $\$ 60$ billion and the outgoing administration's estimate for 1981 was about $\$ 55$ billion.

The incoming president described the situation as "the most serious set of economic problems since the 1930s." The most important cause of these problems, he suggested, was the government itself: through taxes, spending, regulatory policies and monetary policies, it had sacrificed 
Figure 1

Actual Movements vs. Reagan Forecasts of Key Economic Variables

Gross National Product (percent change)

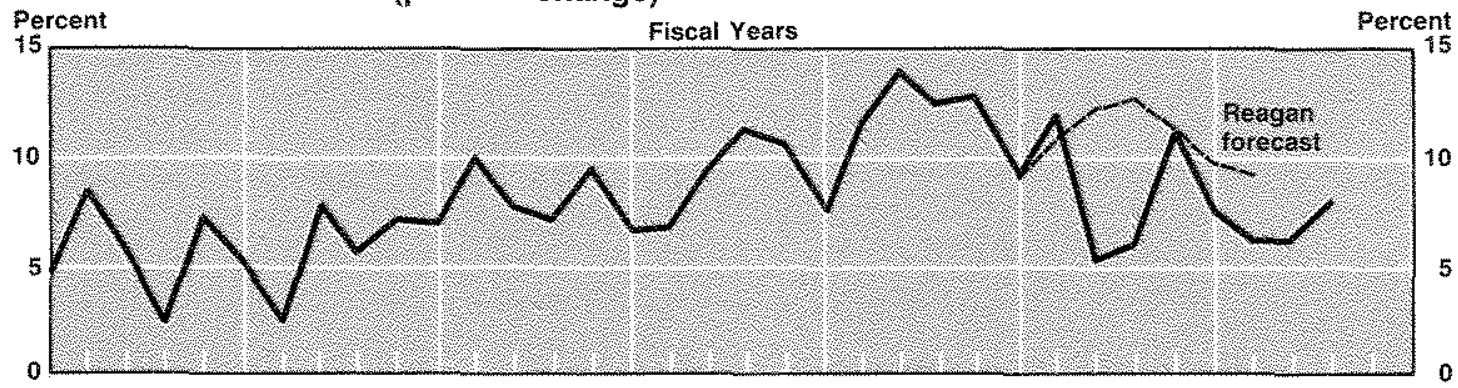

Gross National Product in 1982 Doliars (percent change)

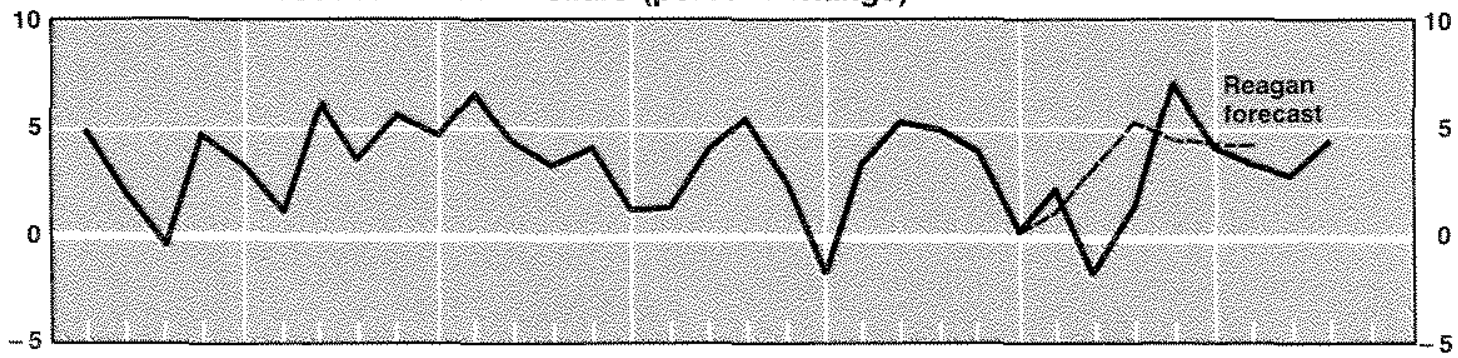

Gross National Product Deflator (percent change)

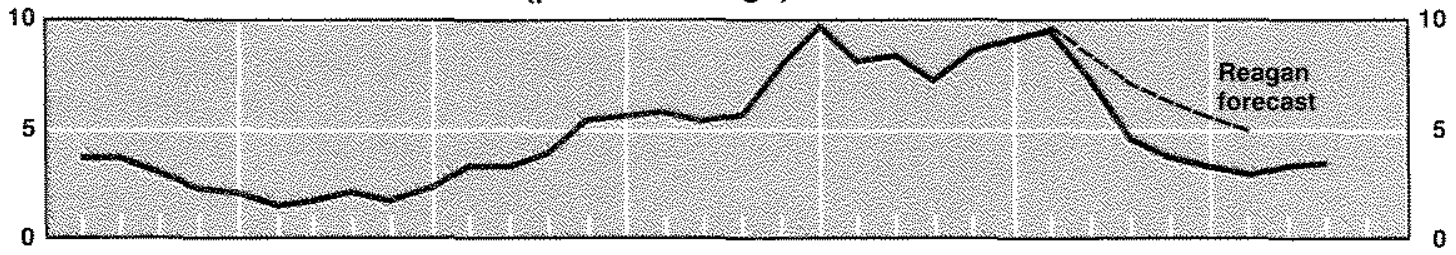

Civilian Unemployment Rate

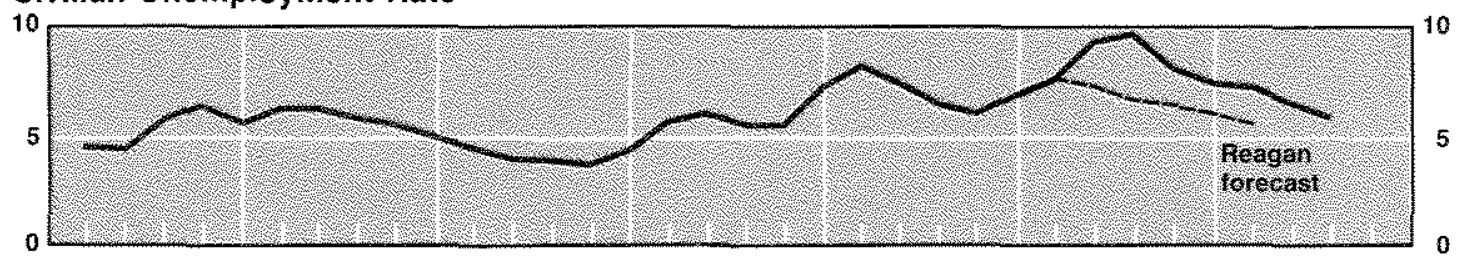

Interest Rate (91-day Treasury bills)

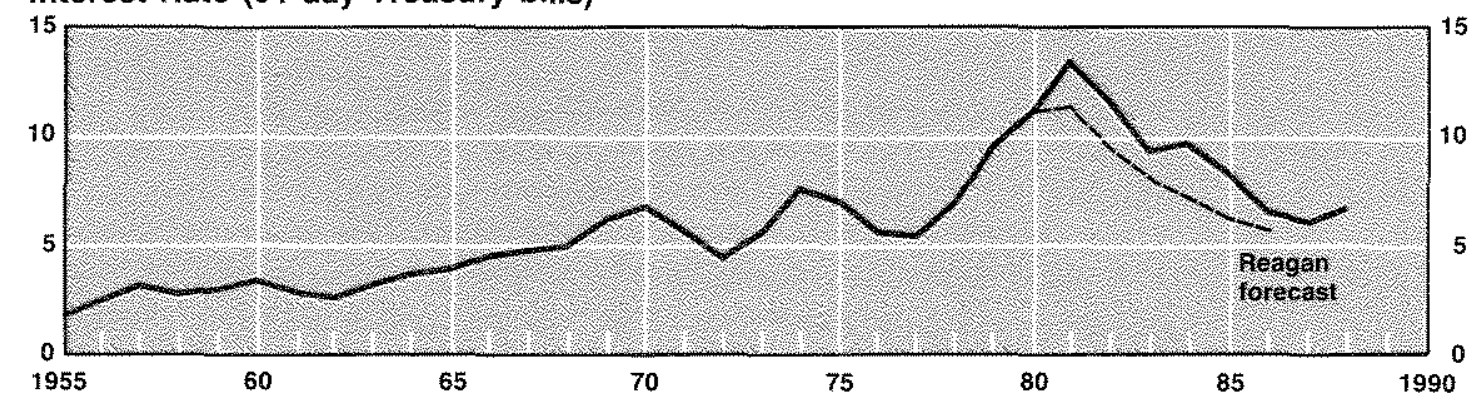


long-term growth and price stability for ephemeral short-term goals. To combat these problems, the administration proposed a program that was intended to:

restore fiscal integrity; increase incentives for saving, investment, and production; attain monetary and financial stability; and enhance the role of the marketplace as the principal force in the allocation of resources. ${ }^{4}$

An important part of every budget program is the set of underlying economie assumptions. Figure 1 shows the administration's 1981 forecasts for a variety of key economic variables along with their actual performance. As the top tier shows, the administration overestimated the growth in nominal GNP from 1980 to 1986 by a substantial amount. ${ }^{6}$ In particular, it did not forecast the 1981-82 recession nor did it foresee the sharp reduction in nominal GNP growth after 1984. By 1986, the cumulative error for GNP was over $\$ 800$ billion, or almost 20 percent of the actual level of GNP in 1986. This error reflected an actual GNP growth rate of 7.8 percent over the 1980-86 period, quite a bit lower than the assumed growth rate of 11 percent.

The overestimate of nominal GNP reflected overestimates of both real growth (second tier of figure 1) and inflation (third tier of figure 1). The cumulative error in forecasts of real GNP by 1986 was 7 percent while the GNP deflator was overestimated by 11 percent. The 1981 administration forecast for inflation for the $1980-86$ period was a 7.1 percent annual rate; the actual inflation rate during this period was 5.1 percent."

The fourth tier of figure 1 indicates that the unemployment rate was underestimated in each of the years from 1981 to 1986 . The administration forecast that the unemployment rate would rise in 1981, then fall to 5.6 percent by 1986 ; the actual 1986 rate was 7.1 percent.
Finally, as indicated in the bottom tier of figure 1, the Treasury bill rate was also underestimated. The Reagan administration forecast a steady decline in the Treasury bill rate from more than 11 percent in 1980 to 5.7 percent in 1986; the actual rate rose sharply in 1981 , before falling to 6.4 percent in 1986.

These key economic variables generally moved unfavorably during the 1980-86 period in terms of their effect on the federal budget. The slowerthan-forecast growth of nominal GNP slowed the growth of receipts and contributed to a larger deficit. Although slower-than-expected inflation helped to reduce the growth of budget outlays, slower real GNP growth and higher-than-forecast unemployment rates increased outlays, particularly for unemployment insurance. Meanwhite, the higher-than-expected Treasury bill rate also boosted outlays, especially when the government was borrowing more than planned. Thus, most of the errors in the administration's forecast were ones that increased the deficit more than projected. ${ }^{\prime}$

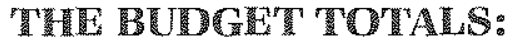

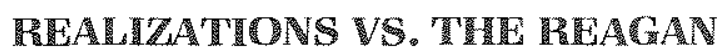 PLAN}

As figure 1 indicated, the Reagan administration's 1981 economic assumptions were erroneous. A related question is to what extent were the budget projections also erroneous? An obvious measure of this particular errot is the difference between the planned and the actual surplus/ deficit. Figure 2 shows the size of this discrepancy. The Reagan plan projected a steady move toward a balanced budget by 1986 ; the actual deficit for 1986 was $\$ 221$ billion. ${ }^{\text {: }}$ To better understand why the 1981 budget plan's projections were in error; individual budget categories are examined below."
${ }^{4}$ bid., p. 9.

${ }^{5} \mathrm{Although}$ such assumptions are absolutely necessary to project outlays and receipts, economic conditions themselves are influenced by congressional and legislative decisions that affect the budget. This was the administration's reasoning in $1981 ;$ its budget programs were designed to have a favorable effect on the economy. In fact, its economic assumptions were so optimistic, it felt compelled to say:

Indeed they do represent a dramatic departure from the trends of recent years mu but so do the proposed polictes. In fact, if each portion of this comprehensive economic program is put in place - quitckly and completely - the ecoromic environment coutd fmprove even more rapidly than envisioned in these assumptions. [lbia., p. 25.]

GGeneralfy, from this point on, all references to years are to fiscal years, i.e., the 12 -month period ending September 30 .
7 Such a projection was not unusual in early 1981. For example, the Congressional Budget Office projected a 1980-86 nominal GNP growth rate in excess of 11 percent. See CBO (1981).

aBy comparison, the CBO projected a 2.8 percent rate of real GNP growth and an 8.5 percent rate of inflation.

FFor a statistical investigation of bias in government economic torecasts, see Belongia (1988).

10Throughout this atticle references to the "Reagan plan" are to the spending program that excluded what they called "unallocated savings." These were cuts in spending for which detail was to be provided later.

"The results of an alternative analysis using a small model of budget determination appears in appendix A. 


\section{Figure 2}

\section{Federal Surplus/Deficit}

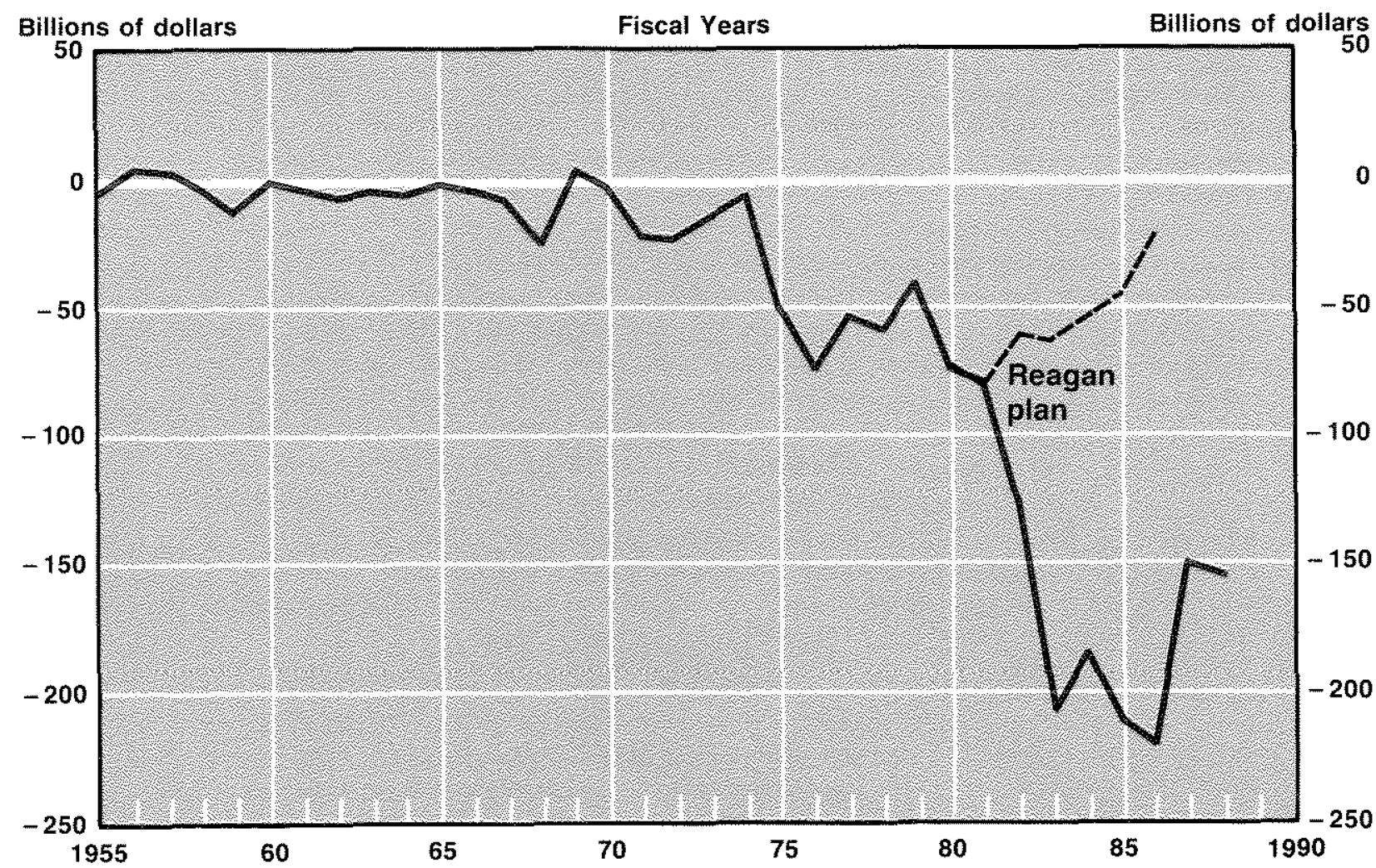

NOTE: Reagan plan does not include "unallocated savings."

\section{Outlays}

One major objective of Reagan's economic program was to

reduce the rate at which government spending increases... Thus, the badly needed effort to "cut" the budget realy refers to reductions in the amount of increase in spending requested from one year to the next."

The 1981 program for reducing the growth of outlays was subject to some confusion, however, because a target ceiling was set which included substantial "unallocated savings" that were to be specified later. In the following discussion, these unallocated savings are ignored.
Figure 3 shows the Reagan plan for real federal outlays along with actual real outlays. Total outlays in real terms clearly did not slow as much as planned. From 1976 to 1980 , the average growth rate of real federal outays was 3.5 percent. The actual rate of increase from 1980 to 1988 was 2.9 percent, only slightly slower than from 1976 to 1980 and well in excess of the 1.1 percent rate that the administration had projected in $\mathbf{1 9 8 1 .}$

As figure 4 shows, another way to summarize budget trends is to examine the ratio of outlays to GNP. From 1955 to 1980 , the ratio of total outlays to GNP rose, albeit irregularly ${ }^{1:}$ Although the Reagan plan intended to reverse this trend sharply after 1981, this did not occur. ${ }^{1 *}$
${ }^{12}$ America's New Beginning . . (1981), p. 10.

${ }^{13}$ This irfegular movement reflects, among other factors, the business cycle as it affects both GNP and tolal outlays.
${ }_{14}^{14}$ The discrepancy in the 1980 ratio between the Reagan plan and the realized outcome reflects the upward revisions of GNP that have occurred since 1981. 


\section{Figure 3 \\ Total Outlays (constant 1982 dollars)}

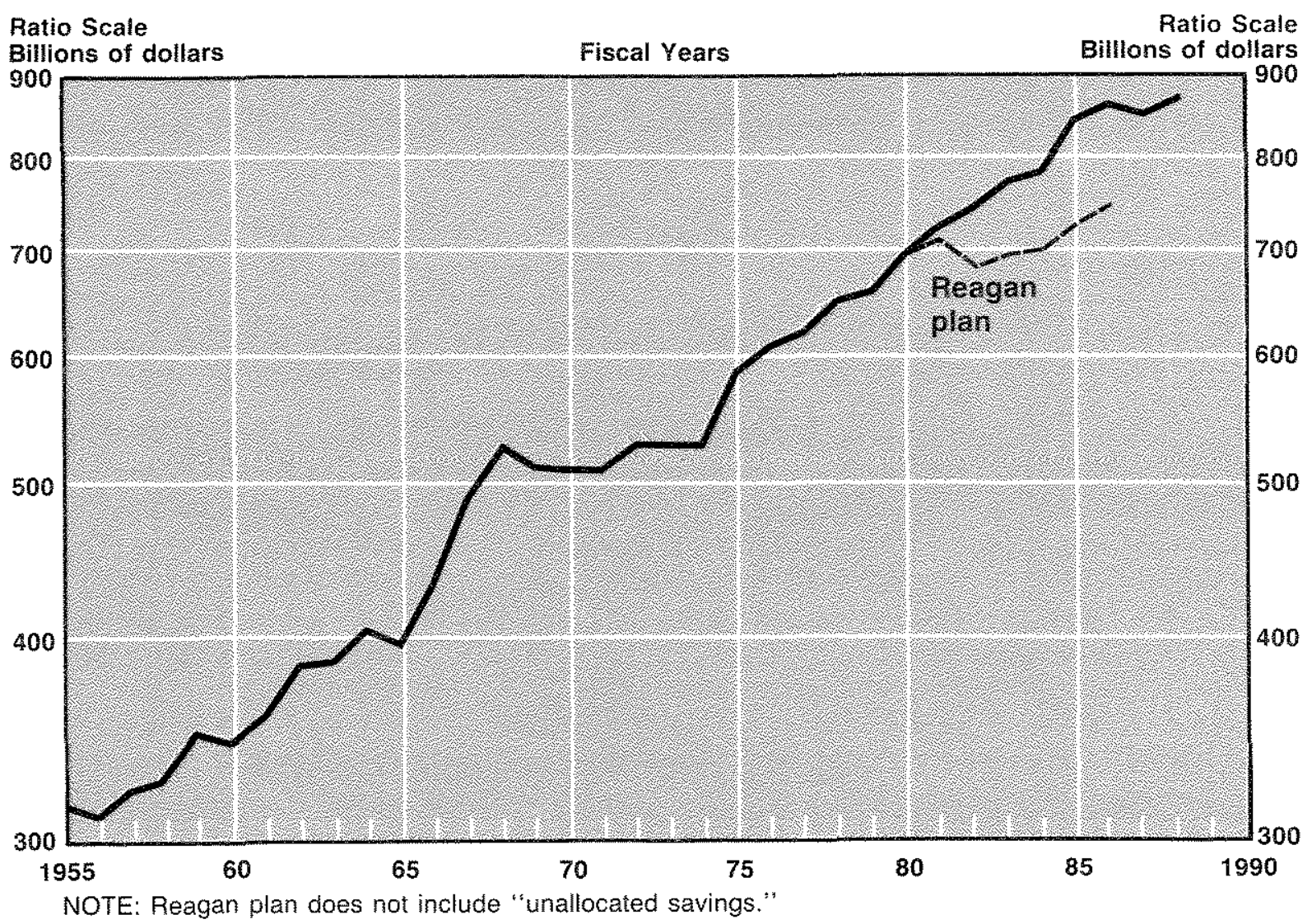

\section{Peceipts}

Another key part of the 1981 economic program was a set of tax proposals that was intended "to improve the after-tax, after-inflation rewards to work, saving, and investment." ${ }^{15}$ Among these proposals were reductions in marginal tax rates for individuals of 10 percent a year for three years starting July 1, 1981, For corporations, the chief feature of the proposed tax changes was an accelerated recovery rate for the cost of machinery and equipment and certain structures to be phased in over five years. In general, the effect of the proposed tax changes was to slow the growth of federal receipts by reducing the role of individual income taxes and corporate income taxes in the revenue structure.
Figure 5 shows the Reagan plan for total receipts along with actual receipts, both converted to constant 1982 dollars. Clearly, the trend of real total receipts slowed after 1981 and was much slower than planned. Real receipts plummeted in 1982 and 1983 due both to the reduction in tax rates and the $1981-82$ recession. Since then, receipts have grown faster than in the 1981 Reagan forecast; because they fell so much in 1982 and 1983, however, their 1986 level was still below that projected by the administration in 1981.

When total receipts are charted relative to GNP (figure 6), the difference between what was planned in 1981 and what actually happened is quite pronounced. In an alternative way, this difference shows the influence of the recession and how it suppressed federal receipts relative to GNP.

${ }^{15}$ America's New Beginning . . . (1981), p. 9. 
Figure 4

Total Outlays Relative to Gross National Product

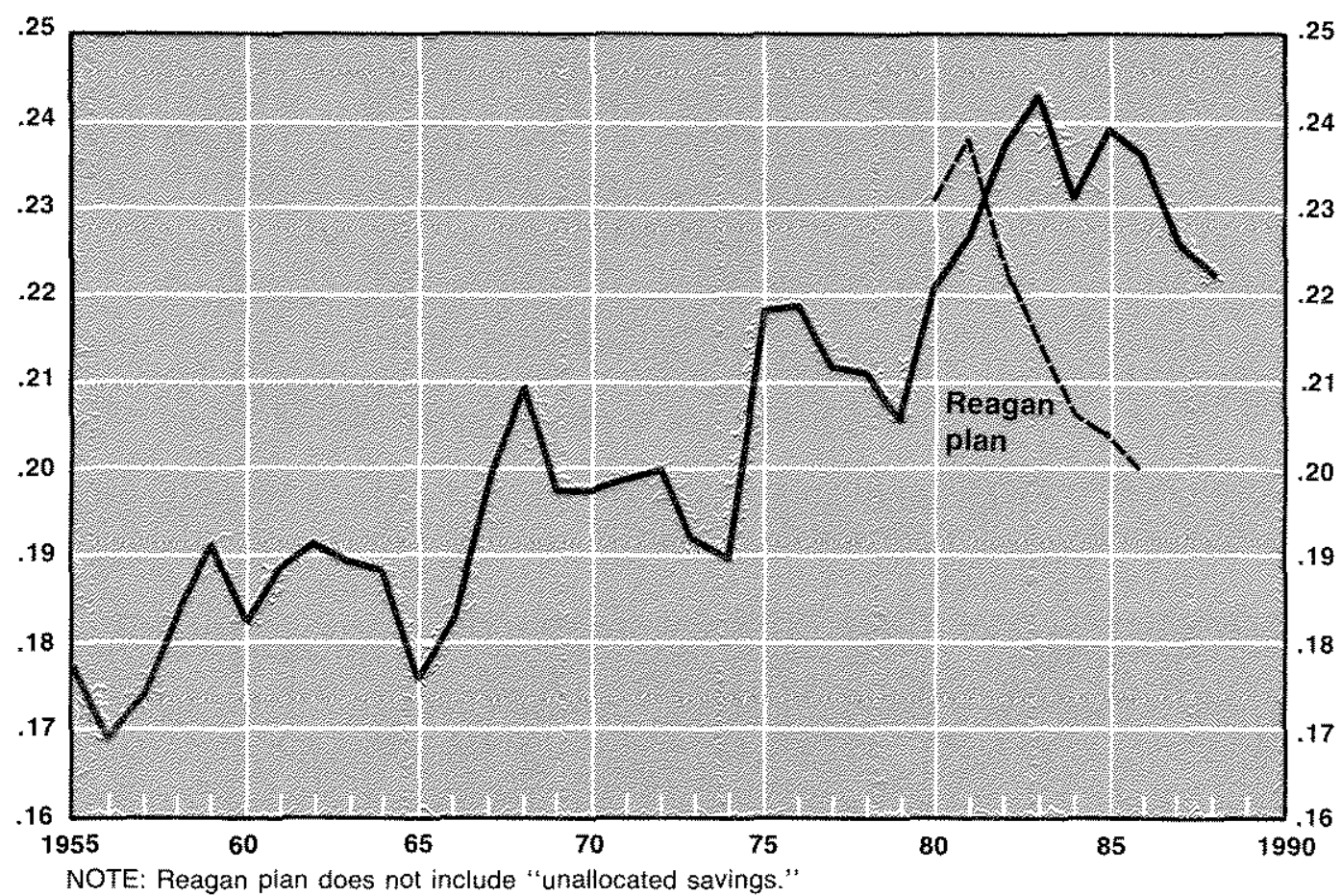

Figure 5

Total Receipts (constant 1982 dollars)

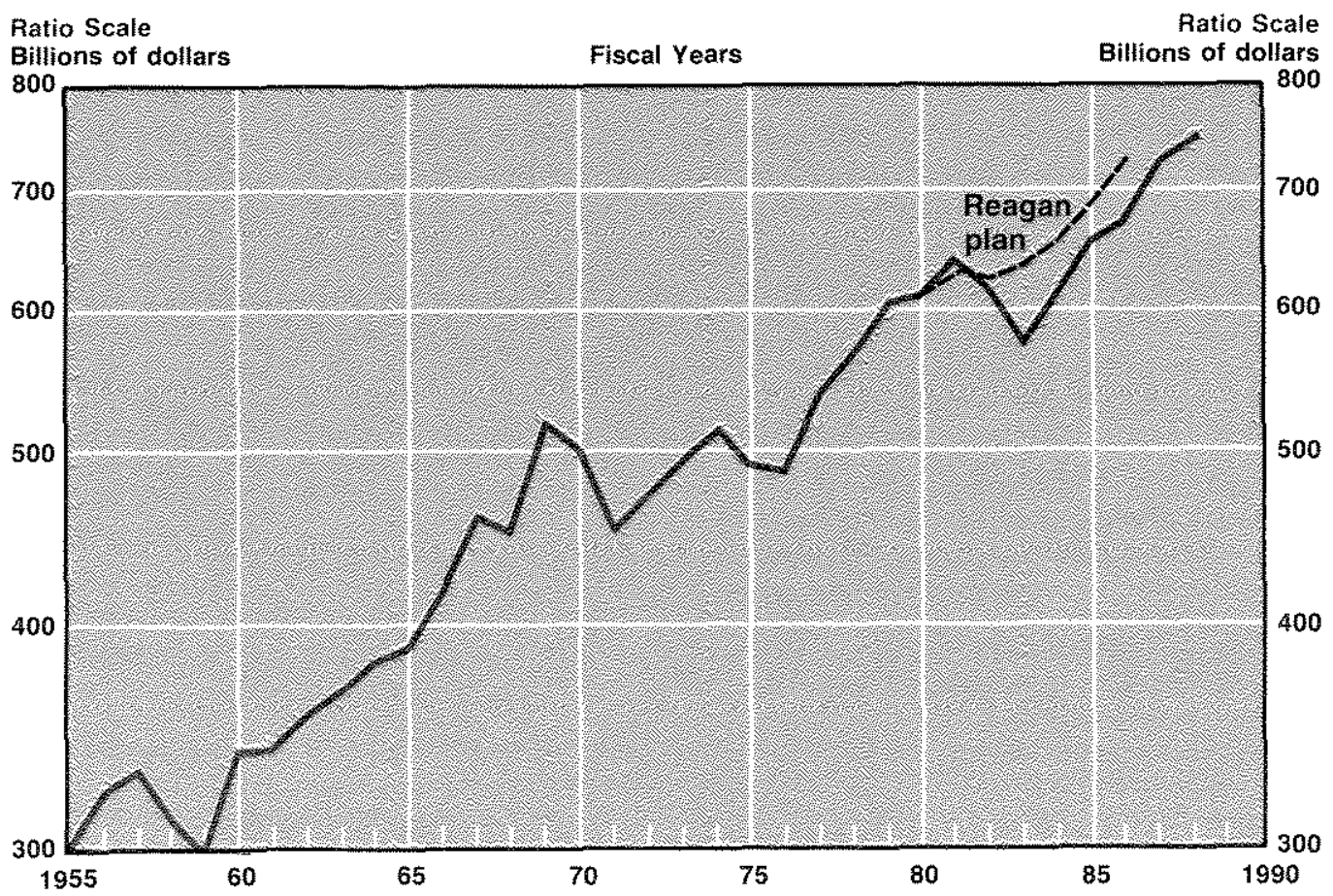




\section{Figure 6}

\section{Total Receipts Relative to Gross National Product}

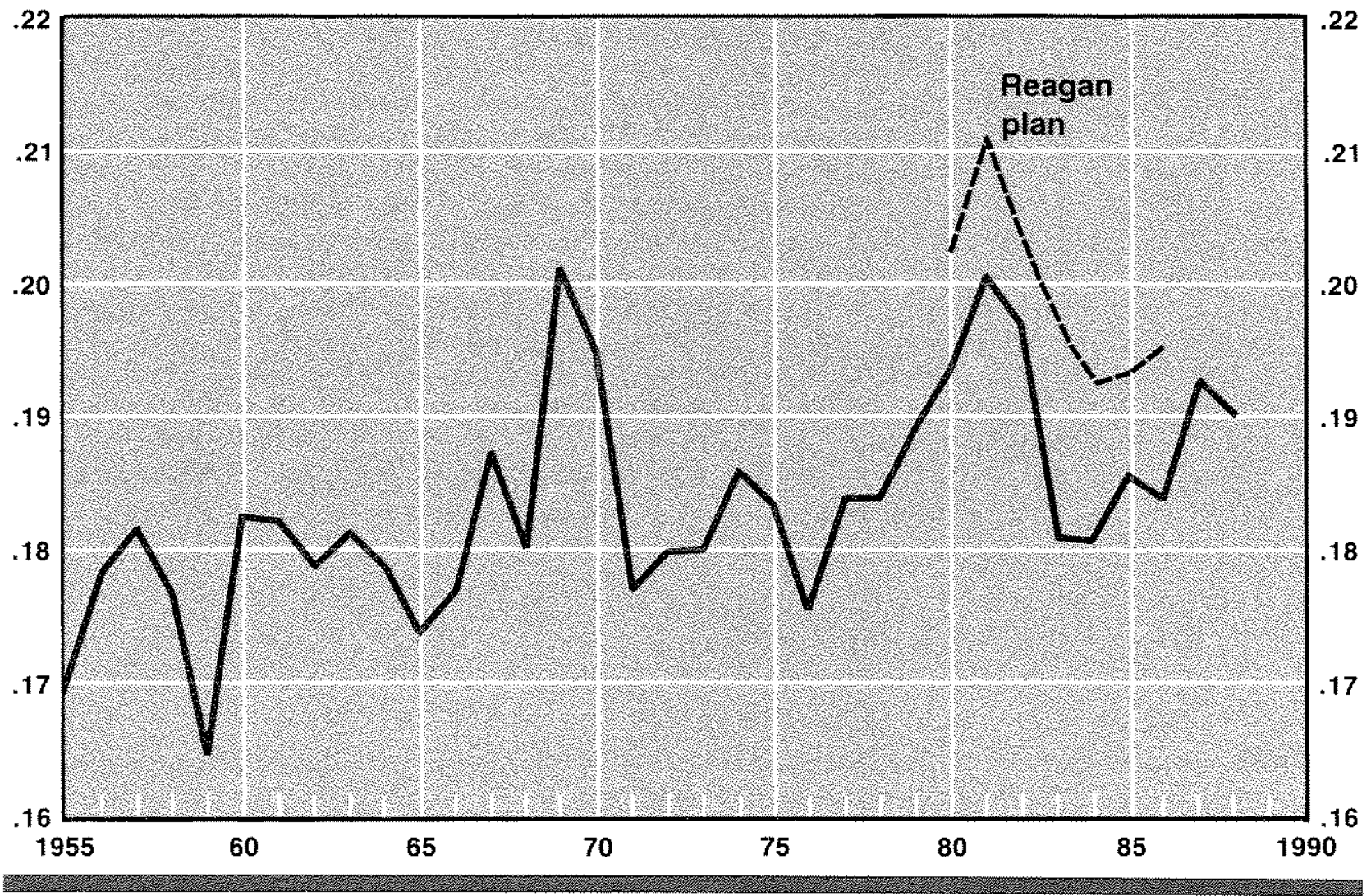

\section{THE COMPOSH ION OF TIE}

\section{BUDGET: PEACAN IDAN}

The 1981 Reagan plan called for both a slowing in the growth of government outlays and a change in the composition of spending and receipts. The change in the composition of outlays was intended to:

shift Federal budget priorities so that Federal resources are spent for purposes that are truly the responsibility of the national government ... our budget plans reflect the increased importance attached to national defense, maintain the Federal Government's support for the truly needy, and fulfill our responsibilities for interest payments on the national debt. The spending reductions will restrain Federal involvement in areas that are properly left to State and local governments or to the private sector. ${ }^{\text {t }}$
The projected composition of total receipts reflected the two major tax changes: tax relief for individuals and greater tax incentives for investment by businesses.

\section{Outlays}

Table 1 shows the major components of outlays relative to total outlays. ${ }^{17}$ The first column shows that the Reagan administration planned to increase national defense outlays from 22.9 percent of total outlays in 1980 to 35.7 percent in 1986.

Although defense outlays did rise, the increase fell short of the planned level; by 1986, defense outlays were 27.6 percent of total outlays. Looking at it in a different way, the planned growth of real defense outlays were projected to grow at an 8.6 percent annual rate from 1980 to 1986 ; their actual rate of increase was 6.2 percent. The actual defense build-up, while slower than planned, did mark a reversal of the previous trend. 
Table 1

Composition of Federal Outlays (percent of total)

\begin{tabular}{|c|c|c|c|c|c|c|c|c|c|c|}
\hline \multirow[b]{2}{*}{ Year } & \multicolumn{2}{|c|}{ Ifaronoloterse } & \multicolumn{2}{|c|}{$\begin{array}{l}\text { Payments } \\
\text { to indivituals }\end{array}$} & \multicolumn{2}{|c|}{ Alloher grants } & \multicolumn{2}{|c|}{ Net inierost } & \multicolumn{2}{|c|}{ molner } \\
\hline & Actrol & moggaplan & Acropl & Alogh ptin & Actial & nergan plar & Actust & forganplon & Actula & nestruplan \\
\hline 1955 & $62.4 \%$ & & $20.9 \%$ & & $2,3 \%$ & & 726 & & $72 \%$ & \\
\hline 1960 & 522 & & 262 & & 4.9 & & $75^{2}$ & & 92 & \\
\hline 1965 & 428 & & 200 & & 6. & & 78 & & 158 & \\
\hline 1970 & 410 & & 33 & & 79 & & 74 & & 9.9 & \\
\hline 1975 & 260 & & 462 & & 100 & & 70 & & 106 & \\
\hline 1980 & 227 & $29.9 \%$ & 40 & $457 \%$ & 10. & $96 \%$ & 89 & $0.8 \%$ & 114 & $18.9 \%$ \\
\hline 1681 & 202 & 289 & 477 & 408 & 85 & 91 & 101 & 94 & 104 & 148 \\
\hline 1682 & 248 & 265 & 478 & $4 / 4$ & 67 & 66 & 144 & 96 & 92 & 99 \\
\hline 1058 & 260 & 2078 & 40.9 & 478 & 6.6 & 50 & 141 & 89 & (1) & 86 \\
\hline 1984 & 26.7 & 310 & 166.9 & 476 & 62 & 64 & 190 & 82 & 71 & 70 \\
\hline 1985 & 267 & 340 & 450 & 46.9 & 61 & 49 & $13 \%$ & 178 & 86 & 69 \\
\hline 1986 & 276 & 357 & 15.4 & 46,4 & 60 & 4 & 16.7 & 65 & 78 & 6.8 \\
\hline 1987 & 28. & & $46 \%$ & & 52 & & 13.8 & & 0.6 & \\
\hline 1806 & 273 & & 469 & & 5. & & 14.9 & & 66 & \\
\hline
\end{tabular}

The nondefense portion of the budget was reduced, but, again, not to the extent that was planned. The plan called for nondefense outlays to fall to 64.3 percent of the total by 1986 ; the actual proportion was 72.4 percent. Table 1 provides further detail on nondefense outlays. While the plan for payments to individuals, relative to total outlays, seems close to the mark, the growth rate comparison shows a different story. Individual payment outlays rose faster than planned in real terms; the planned increase was a 1.6 percent average annual rate from 1980 to 1986 compared with the actual 2.8 percent rate of increase.

For the category of "all other grants" the third column of table 1 , the planned decline was realized in the first two years, but not afterward. Although grants in real terms fell rather dramatically at a 4.8 percent rate from 1980 to 1986 , this was still less than the 10.7 percent rate of decline planned by the 1981 administration.

The fourth column of table 1 shows the most dramatic departure from the 1981 plan. Net interest outlays were forecast to decline sharply; instead, however, they rose sharply. Because this component of outlays cuts across all factors that affect the budget and reflects the general interaction of the budget with the economy, this forecast error serves as a summary measure of the accuracy of both the budget plan and the economic forecast. ${ }^{18}$ Because outlays grew faster than planned while receipts rose more slowly, net interest outlays were twice as large as planned in 1981. Errors in receipts (overestimated) and outlays (underestimated), combined with an underestimate of interest rates, produced these large errors.

The final "all other" category of outlays shows a decline very close to, but generally somewhat less than planned.

\section{Receipts}

Table 2 shows the components of receipts relative to the total. The first column, individual income taxes, reflects the ambitious nature of the 1981 tax proposal. The administration proposed a 30 percent reduction in marginal tax rates for indi viduals over a three-year period beginning July 1 , 1981. Marginal rates were to be reduced from an existing range of 14 percent to 70 percent to a range of 10 percent to 50 percent by January 1 , 1984. This proposal was expected to reduce individual income taxes from near 47 percent of total receipts in 1980 to 43.9 percent in 1983; the per centage was then forecast to rise to 46.7 in 1986 because of its expected stimulus to activity via incentives to work and invest.

The general movement of individual income taxes relative to the total went according to plan;

185ee appendix A. 


\section{Table 2}

\section{Composition of Federal Recelpts (percent of total)}

\begin{tabular}{|c|c|c|c|c|c|c|c|c|c|c|}
\hline \multirow[b]{2}{*}{ reor } & \multicolumn{2}{|c|}{$\begin{array}{l}\text { Imandal } \\
\text { icome tares }\end{array}$} & \multicolumn{2}{|c|}{ Corporation } & \multicolumn{2}{|c|}{ 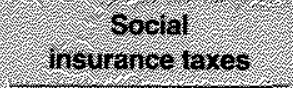 } & \multicolumn{2}{|c|}{ Ercise tares } & \multicolumn{2}{|r|}{ ongr } \\
\hline & Actual & forgan plan & Actuat & neggon plar & Actul & reagar plar & Alust & Reagan plan & Actual & Reagan plan \\
\hline 1058 & $48,8 \%$ & & 2766 & & (2. 10 & & $139 \%$ & & $29 \%$ & \\
\hline 1860 & 440 & & 232 & & 159 & & 126 & & 42 & \\
\hline 1965 & 418 & & 268 & & 180 & & 125 & & 4.9 & \\
\hline 1970 & 469 & & 170 & & 230 & & 81 & & 4.9 & \\
\hline 1975 & 439 & & 143 & & 30.8 & & 59 & & 5.4 & \\
\hline 1980 & 472 & $469 \%$ & 12.5 & $12 \% 4 \%$ & 305 & $309 \%$ & 47 & $47 \%$ & 5.1 & $5.1 \%$ \\
\hline 188 & 477 & 462 & 102 & 108 & 305 & 31 & 68 & 73 & 48 & 47 \\
\hline 1982 & 482 & 448 & 610 & 96 & 826 & 360 & 5.9 & 66 & 5.4 & 48 \\
\hline 1980 & 48, & 439 & 62 & 97 & 34.8 & 338 & 5.9 & 80 & 6.1 & 46 \\
\hline 1984 & 4.68 & 44.1 & 86 & 9. 3 & 059 & 342 & 56 & 76 & 52 & 49 \\
\hline 1005 & 466 & 451 & 84 & 84 & 36. & 348 & 49 & 70 & 61 & 16 \\
\hline 1986 & 454 & 46.7 & 82 & 77 & 868 & 348 & 40 & 64 & 52 & 43 \\
\hline 1987 & 460 & & 96 & & 35.3 & & 36 & & 49 & \\
\hline 1986 & 14. & & 104 & & 368 & & 39 & & 48 & \\
\hline
\end{tabular}

the timing, however, was substantially different for several reasons. One of these was the timing of the actual legislation. What's more, an unanticipated recession occurred, and the anticipated boom in economic activity that was expected to follow on the heels of the tax program failed to develop.

The second column of table 2 summarizes corporate income taxes. Again, the Reagan plan was broadly realized. Corporate taxes were reduced and their role in the tax system was reduced, at least through 1986. The planned and the actual percentages were quite close in 1986, although the actual path of arrival from 1981 to 1986 was somewhat different than planned. Corporate income taxes were severely affected by the $1981-82$ recession, dropping as a percentage of total receipts in 1982-83. Despite the erroneous economic forecast, however, the general contours of the Reagan corporate tax plans were realized. This pattern has been reversed since 1986, however; the Tax Reform Act of 1986 tightened provisions for accelerated depreciation of plant and equipment and repealed the investment tax credit. These results have cancelled, to some extent, the effects of the 1981 tax act.

The evolving role of social insurance contributions in the tax system is shown in the third column of table 2 . The actual ratio followed the plan very closely through 1982 , but moved well above the forecast after that. "This divergence reflected mainly the 1983 social security amend- ments that accelerated collections to keep the social security program afloat.

The fourth column of table 2 shows the propor tion of excise taxes to total receipts. The $\mathbf{1 9 8 1}$ Reagan administration forecast a sharp increase in 1981 and 1982 , followed by a steady decline. This general pattern occurred, except that the peak was in 1981 and was at a much lower level than forecast. The discrepancy between what was planned and what actually occurred was mainly the result of much smaller than expected gains from the windfall profits tax; oil price forecasts were erroneous

Finally, the "all other" category, which is unimportant relative to the total, was underestimated. The major taxes in this category are estate and gift taxes, customs duties and Federal Reserve deposits. The dollar amount of all other receipts was forecast accurately; because the total was overestimated (figures 5 and 6 ), however, "all other" receipts as a proportion of the total was underestimated.

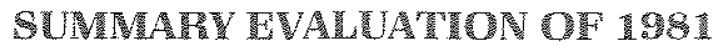

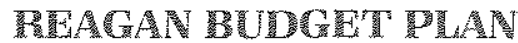

Table 3 summarizes the 1981 Reagan budget plan and compares its individual components with trends prior to 1981 and what actually occurred after 1981. Rates of change for budget totals 


\section{Table 3}

\section{Federal Budget Trends and the Reagan Plan (constant fiscal year 1982 prices, annual rates of change)}

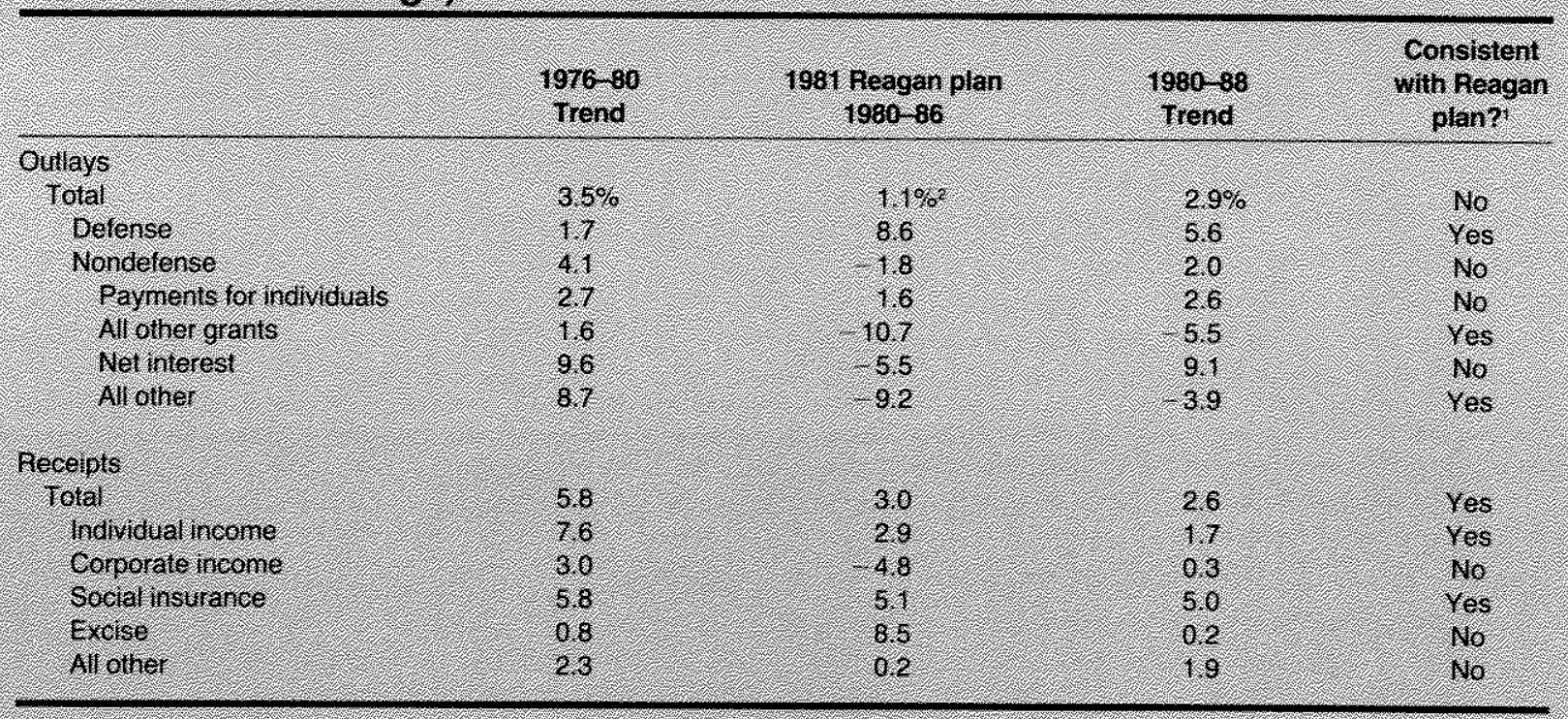

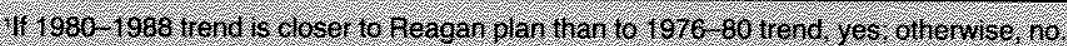

Thellung unallecated savings, the rate of chatige was 0.3 pereent

and their major components are calculated from the constant dollar measures. A broad judgment is reached on whether actual performance was consistent with the Reagan plan depending on whether the actual $1980-88$ trend was closer to the Reagan plan than the prior $1976-80$ trend.

The 1980-88 total outlay performance was in. consistent with the 1981 plan. Although the annual growth rate of total real outlays slowed from a 3.5 percent rate to a 2.9 percent rate, this was still substantially above the Reagan estimate of $\mathbf{1 . 1}$ percent. Total real receipts, on the other hand, grew at a rate consistent with the 1981 plan; they actually slowed more than planned because of the 1981-82 recession.

An examination of the growth of the components of real outlays shows that some moved in a direction consistent with 1981 plan. Real defense outlays did not rise as much as planned; however, their growth accelerated substantially from the 1976-80 period. Although real nondefense outlays grew much more slowly, the Reagan plan called for a decline. The components of real nondefense outlays showed mixed results. Growth in real payments for individuals and net interest slowed only slightly. The other two categories, however, showed a sharp reversal from the prior four years, although not as much as was planned.

Though real total receipts moved consistently with the Reagan plan, the components of the total showed mixed results. Real individual income taxes rose more slowly than planned, chiefly because economic growth was overestimated, but their growth was down sharply from the 1976-80 trend. Real corporate income taxes slowed, but not to the extent outlined in the 1981 plan. Real social insurance contributions grew at rates very close to what was forecast in 1981. Both the excise and "all other" components of total receipts were estimated incorrectly, but this had little consequence since they are such small proportions of total receipts.

\section{CONCUUSON}

In 1981, the newly inaugurated Reagan administration formulated a budget plan designed to slow the growth of government and boost incentives (via taxes) to save, invest and work. Included in the projections was a movement toward a balanced federal budget by 1986. The actual rise in the federal deficit since 1981 , culminating with a $\$ 221$ 
billion deficit in 1986, suggests that the Reagan budget program failed. Examination of the factors contributing to the deficit as well as the composition of both outlays and receipts, however, indicates broadly why this result occurred and points out that there were a number of successes as well as failures when individual components of the federal budget are considered.

Total receipts in 1986 were overestimated by about $\$ 170$ billion, mainly because the $1981-82$ recession was not anticipated. The major tax proposals were adopted, although not in their exact form nor according to the proposed timetable. Because of differences in timing and subsequent legislation, the actual composition of total receipts varied somewhat from the 1981 projections. The direction of movement, however, was generally as projected for individual income taxes, corporate income taxes and social insurance contributions. The largest егтог in the projected composition of total receipts was for excise taxes, chiefly because the forecast of oil prices was in error with the result that the windfall profits tax did not produce revenues as expected.

Total outlays were underestimated by about $\$ 30$ billion in 1986 (or more than $\$ 70$ billion if the 1981 estimate includes "unallocated savings"). Further examination of outlays revealed a $\$ 73$ billion error in the projection of net interest. This error was largely offset, however, because the actual defense build-up fell about $\$ 69$ billion below projections by 1986 . The noninterest portion of nondefense spending was underestimated by $\$ 15$ billion, or 5 percent.

In general, if one looks at budget outlays, the Reagan program enjoyed some success: the decline in the relative role of defense outlays was reversed; payments for individuals relative to total outlays continued roughly as planned; all other grants and the residual category of "all other out- lays" continued to decline from their peaks in the late 1970 s or 1980 . The major exception to the 1981 plan was the rise in net interest outlays produced by failures to forecast the $1981-82$ recession (which slowed the growth of receipts), the level of interest rates, and the cumulative effect on outlays of compounding interest on a growing national debt. ${ }^{.1}$

\section{REFERENCES}

America's New Beginning: A Program for Economic Recovery (The White House, Office of the Press Secretary, February 18, 1981$)$.

Betongia, Michaet T. "Are Economic Forecasts by Government Agencies Blased? Accurate?" this Review (November/Decem. ber 1988), pp. 15-23.

Boskin, Michael d. Reagan and the Economy (ICS Press, 1987).

Carlson, Keith M. "Trends in Federal Revenues: 1955-86," this Review (May 1981), pp. 31-39. "Trends in Federal Spending: 1955-86," this Review (November 1981), pp. 15-24.

"The Critical Role of Economic Assumptions in the Evaluation of Federal Budget Programs," this Review (Octo" ber 1983), pp. 5-14.

"Money Growth and the Size of the Federal Debt" this Review (November 1984), pp. 5-16.

Congressional Budget Office. An Analysis of President Reagan's Budget Revisions for Fiscal Year 1982, Staff Working Paper (March 1981).

Mils, Gregory B, and John L. Palmer, eds. Federal Budget Policy in the 1980s (The Urban Institute Press, 1984).

Mogigliani, Franco. "Reagan's Economic Policies: A Critique," Oxford Economic Papers (September 1988), pp. 397-426.

Niskanen, William A. Reaganomics (Oxford University Press, 1988 ).

Office of Management and Budget. Fiscal Year 1982 Budget Revisions (March 1981a).

Federal Government Finances (March 1981b).

Historical Tables, Budget of the United States Government Fiscal Year 1990 (U.S. Government Printing Office, 1989).

19See appendix A and Carlson (1984). 


\section{Appendix A \\ The Impact of Economic Assumptions on the 1981 Reagan Budget Plan}

An alternative method of evaluating the 1981 budget plan is to simulate the effect on the budget of economic conditions different from those assumed in planning the budget. An updated version of a budget model previously presented in this Review was used to do this. 'The model con" sists of three parts: an estimate of the impact of inflation and real growth on both (1) primary receipts and (2) primary outlays, and (3) an estimated equation for net interest outlays. The latter reflects the indirect effects of inflation and real growth on receipts and outlays as well as the effect of interest rate changes.

First, the 1981 Reagan budget plan was separated into primary receipts, primary outlays and net interest (see table A1). The effects of actual inflation, real growth and interest rates then were calculated, yielding simulated values of primary receipts and outlays and interest cost for the 1981-86 period. These simulation results are shown in table $\mathrm{A} 2$.

\section{Table A1}

\section{The 1981 Reagan Budget Plan (billions of dollars)}

\begin{tabular}{|c|c|c|c|c|c|c|c|c|}
\hline Year & $\begin{array}{l}\text { Primary } \\
\text { recerpls }\end{array}$ & $\begin{array}{l}\text { Prinary } \\
\text { oullays }\end{array}$ & surpluspericit & 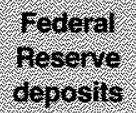 & $\begin{array}{l}10 \mathrm{tar} \\
\text { receipls }\end{array}$ & $\begin{array}{l}\text { Net } \\
\text { nterest }\end{array}$ & $\begin{array}{l}\text { Toral } \\
\text { outiays }\end{array}$ & $\begin{array}{l}\text { Suplus } \\
\text { defict }\end{array}$ \\
\hline 1980 & 8506.3 & 5541.4 & 86 & 1118 & 8520.1 & 8625 & 8596.9 & 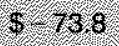 \\
\hline 198 & 5877 & 6147 & 27.0 & 2126 & $600 \%$ & 64,1 & 678.8 & 2.785 \\
\hline 1982 & 6370 & 648.8 & 6.8 & 183 & 650.3 & 682 & 1720 & 64,7 \\
\hline 1983 & 6940 & 7008 & 9.5 & 15. & 709 & 689 & $7 / 12.4$ & 63.3 \\
\hline 1984 & 1522 & 2756 & 8.9 & 18.5 & 1707 & 678 & 8239 & 53.2 \\
\hline 1985 & 83.12 & 00002 & 10 & 167 & 849,9 & 649 & 8951 & 452 \\
\hline 1880 & 9213 & 8096 & $2 \%$ & 189 & 8402 & $6 \% 8$ & $(96) 2$ & 210 \\
\hline
\end{tabular}

\section{Table A2}

\section{The 1981 Reagan Budget Plan: Simulated' (billions of dollars)}

\begin{tabular}{|c|c|c|c|c|c|c|c|c|}
\hline Year & $\begin{array}{l}\text { Primay } \\
\text { recelpss }\end{array}$ & primagy & surplostatict & $\begin{array}{l}\text { rederal } \\
\text { roseryl } \\
\text { deposts? }\end{array}$ & $\begin{array}{l}\text { Trata } \\
\text { recelprs; }\end{array}$ & $\begin{array}{c}\text { Mot } \\
\text { nterest }\end{array}$ & $\begin{array}{l}\text { Total } \\
\text { outiays }\end{array}$ & $\begin{array}{l}\text { surplus } \\
\text { gefiel }\end{array}$ \\
\hline 1980 & $\$ 5083$ & 8547,4 & S. 931 & 51.8 & 85201 & 852.5 & 85909 & 6.738 \\
\hline 1981 & 5912 & $613 \times 4$ & 2.282 & 129 & 6040 & 70.9 & 6813 & 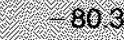 \\
\hline 1982 & 6160 & 6502 & 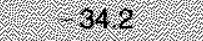 & 152 & 6372 & 865 & 7367 & 1055 \\
\hline 1983 & 611.4 & 7110 & 1002 & 14.5 & 625.6 & 970 & $808 \%$ & 1027 \\
\hline 1984 & 6006 & 77476 & 21090 & (5. & 654.3 & $1,1,3$ & 6589 & 2046 \\
\hline 1965 & 6890 & 8104 & 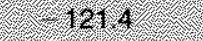 & $17 \%$ & 7061 & 1240 & 9347 & 2286 \\
\hline 1986 & 7255 & 6647 & $2=139.2$ & 18.4 & 7,39 & 134.5 & 9992 & 253.3 \\
\hline
\end{tabular}

'See Carlson (1984), appendix $B$, for a summary of the model.

The only difference from that model is that the interest cost

equation was reestimated with data through 1986. For an ex.

tended discussion of the role of economic assumptions in

budget estimates, see Carlson (1983). 


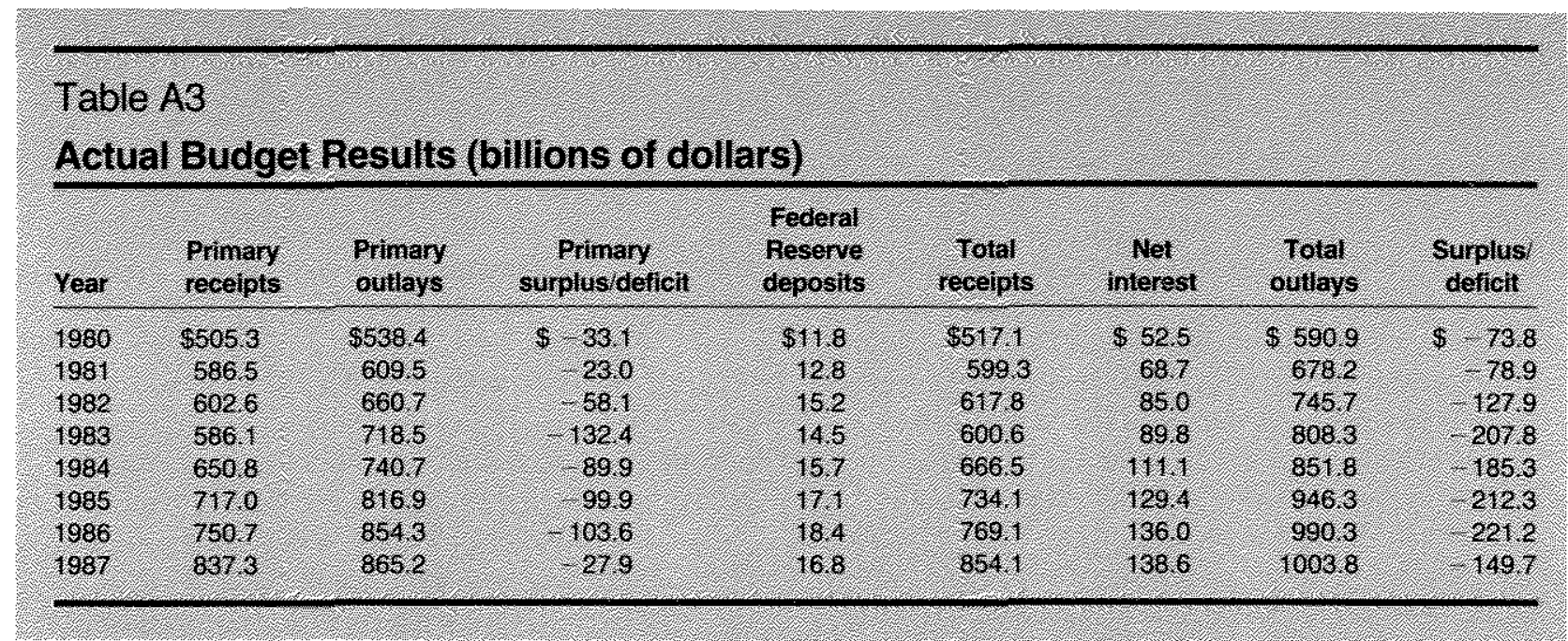

The results indicate that had the 1981 budget plan been fully implemented, it would have yielded a deficit of about $\$ 255$ billion in 1986 . These results are based on the actual course of inflation, real growth and interest rates from 1981 to 1986 . Since the actual 1986 deficit was $\$ 221$ billion (see table A3), apparently the 1981 program was not implemented as planned. Specifically, from 1981 to 1986, neither total receipts nor pri- mary outlays increased to the extent originally planned; total outlays increased more than planned because of large errors in estimating net interest. Thus, the actual behavior of key economic variables "overexplains" the deficit. That is, if primary receipts and outlays had performed according to the 1981 plan, the 1986 deficit would have been much larger than it turned out to be. 


\section{Appendix B \\ Composition of Federal Outlays}

Federal outlays can be classified in terms of two analytical structures: budget function and major program category. The functional classification presents outlays according to the purpose that a federal program is intended to serve. These functions include, for example, national defense, international affairs, energy programs, transportation, health, income security, etc. Two additional categories - net interest and undistributed offsetting receipts - do not address specific functions, but are included to cover the entire budget.

The classification of federal outlays by major program category focuses on the method of carying out an activity. The major program categories are national defense, benefit payments for individuals, grants to state and local governments (other than for benefit payments), net interest and all other outlays, National defense and net interest correspond to the functional categories of the same name, but the remaining major program categories do not correspond to a simple summing of functional categories. Nonetheless, approximations can be made. The accompanying table groups 1988 outlays by function to provide added information about the major program categories discussed in the text.

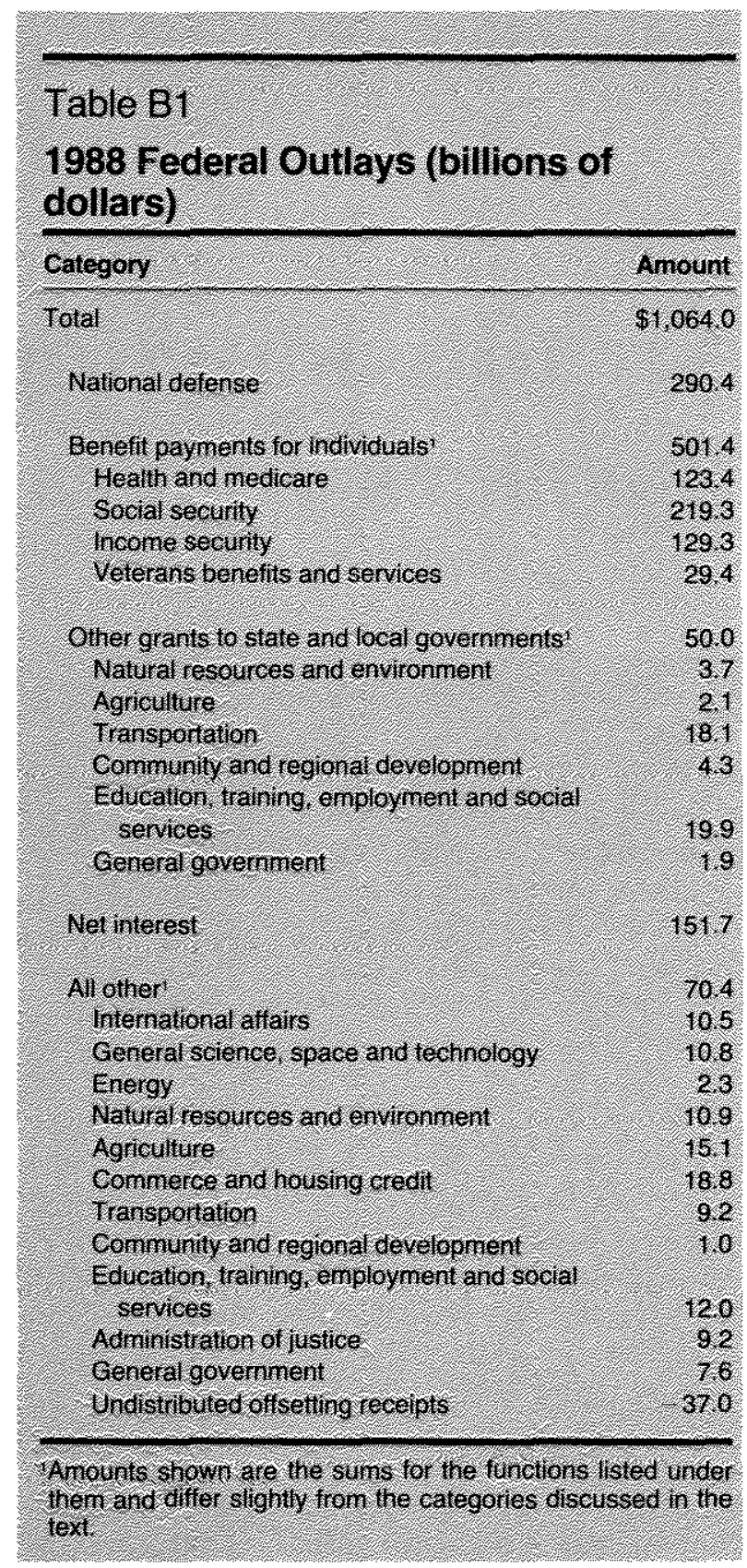

